\title{
Managerial Cash Compensation, Government Control and Leverage Choice: Evidence from Chinese Listed Firms
}

\author{
LU Jia Wei ${ }^{1, a}$, CHEN Wen Qiang ${ }^{2, b}$, JIA Sheng Hua ${ }^{3, c}$
}

1,2,3 Room 705-01, Administration Building, Zijingang Campus of Zhejiang University, Xihu District, Hangzhou, Zhejiang Province, China.

a lujiawei@zju.edu.cn , b790707026@qq.com , c jsh@zju.edu.cn

Keywords: managerial compensation, leverage choice, transition economy, government control, China.

\begin{abstract}
This paper investigates the relationship between managerial cash compensation and firm leverage decision for a sample of China's publicly listed firms during the period of 2003 2015. This paper employs simultaneous equation models to address the potential endogeneity caused by joint determination between managerial compensation and leverage. We find that cash compensation will motivate risk-taking behavior in capital structure decision of the firm. And ownership type will moderate the relationship between managerial cash compensation and capital structure. Management of government controlled firms will be less risk-taking on capital structure decisions although the same level of cash compensation is provided. Our results have significant implications for the design of compensation packages to achieve an appropriate risk-taking level of firm capital structure decision.
\end{abstract}

\section{Introduction}

Since Jensen and Meckling (1976) initially put forward the agency theory, the conflict between manager and stockholders has long been a hot issue of corporate governance field [1]. However, previous studies on capital structure generally presume manager's interest is perfectly aligned with stockholders'. Management-stockholders conflict will induce managers to make major financial policy decisions, such as capital structure decision, that are suboptimal from the shareholders' standpoint (Mehran, 1992) [2]. Management may be risk-averse and choose low leverage ratio to avoid potential bankruptcy risk that will damage their reputation or future career opportunity. However, several studies have attempted to investigate the relationship between managerial compensation and firm leverage decision.

Managerial compensation has a direct impact on manager objectives and thus affects management's choice of firm risk (Carlson and Lazrak, 2010) [3]. The finance literature has provided evidence of the incentive effect of equity-based compensation on awarding management to overcome managerial risk aversion (e.g. Gury, 1999; Coles et al., 2006) [4,5]. However, those studies mainly focus on the compensation method of equity-based compensation (e.g. Rajgopal and Shevlin, 2002; Low, 2009), which has just been introduced into Chinese listed companies and lack empirical support [6,7]. Cash compensation is the most commonly applied compensation method in Chinese firms, while seldom studies attempt to go directly to our question of whether management cash compensation will have observable implication on risk-taking behavior in leverage decisions.

The purpose of our study is to fill this void in the literature by examining how managerial cash compensation affects management's risk-taking in decisions about firm leverage ratio for a sample of Chinese publicly listed firms during the period of 2003-2015. In particular, China has witnessed impressive economic growth since market reforms were introduced in the 1980s. The market reforms lead to greater power of managers on decision-making processes of the enterprise (Firth et al., 2006)[8]. 
However, government control is still one of the most outstanding features of Chinese listed firms. Therefore, this research is interested in the impact of government control on the relationship between management cash compensation and risk-taking in leverage decision. Will government control enhance or weaken the relationship? Chinese listed firms provide us the perfect sample to investigate the potential moderating effect of government control. Our study adds to the literature of ownership by focusing on the impact of government control. Also this study provides robust empirical evidence regarding the contextualization of Chinese publicly listed firms.

The remainder of the paper is organized as follows. Section 2 provides literature discussion, describes the institutional background and develops hypotheses. While Section 3 discusses research method and sample construction. The results are discussed in Section 4. Section 5 concludes the paper and discusses the implications of this paper.

\section{Theoretical Foundation, Institutional Background and Hypotheses Development}

Managerial Compensation and Risk-taking. Faccio (2011) has argued that,“...Understanding the determinants of risk-taking helps identify channels through which policy changes can improve economic welfare"[9]. Due to the agency problem between managers and shareholders, managers will maximize their own interest and not necessarily make decisions that maximize shareholders' interest (Jensen, 1986)[10]. Managers usually hold large amounts of their financial and human capital in the companies they manage, which make their firm-specific human capital non-diversifiable (Mehran, 1992) [2]. So managements are likely to take fewer risks than optimal to avoid potential damage to their professional reputation (Cohen et al., 2000) [11].

One strand of literature, building on the seminal work of agency theory, argue that managerial incentive can be awarded to managers to overcome risk aversion, so that executives will respond to incentives and take on optimal risk-taking behavior. Guay (1999) initially tests the sensitivity of CEO wealth to equity risk [4]. He illustrates that managers receive incentives to invest in risky projects. The convexity of payoff structure from managerial incentive can be more than offset by concavity of the utility function of the risk-averse manager. Cohen et al., (2000) use the Hall-Liebman CEO stock option holding database for periods of 1980-1994 and find that executive stock options provide managers with incentives to take actions that increase firm risk, which is measured by stock return volatility or leverage ratio [11]. Rajgopal and Shevlin (2002) choose a sample of oil and gas CEOs for the period 1992-1997 and then examine the relation between stock option compensation and the variation of future cash flows from exploration activity (the proxy for risk-taking)[6]. They find sample firms exhibiting positive association between exploration risk and sensitivity of executive stock options to stock return volatility. Especially, they adopt a simultaneous equations approach to treat the endogeneity problem. Coles et al. (2006) go more directly to the question of whether managerial incentives have observable operational and policy implications (including investing in riskier R\&D investment programs, adopting higher leverage, and higher volatility of stock returns)[5]. Their finding suggests that higher sensitivity of CEO wealth to stock volatility (vega) implements riskier policy choices. Besides, riskier policy choices in turn will lead to higher vega, implies the endogeneity problem caused by joint determination between managerial incentives and risk-taking. Low (2009) takes the changes in the Delaware takeover regime as an exogenous shock and examines the effect of equity based compensation on managerial risk-taking behavior [7]. He finds that providing managers with greater equity-based incentives will encourage risk-taking behavior and then increase shareholder wealth.

In another strand of related literature, managerial incentives are considered as irrelevant to risktaking. Ross (2004) argues the folklore that giving options to agents will make more willing to take 
risks is false [12]. He illustrates his argument through a series of theoretical derivations and pointed out no incentive schedule will make all expected utility maximizers less risk averse. What's more, options may even have a magnification effect and lead to more risk aversion. Grant et al. (2009) demonstrate that, "...CEOs appear to shy away from the effects of risk, rather than respond positively to the risk incentives supposedly created by option plans..." using a sample of 500 American companies for the period 1992-2003 [13].

The controversial conclusions between managerial incentive and risk-taking discussed above are mainly drawn from the empirical evidence using equity-based managerial compensation. However, equity-based compensation was first allowed in Chinese listed firms at the end of 2005, when "The Trial Measures for the Administration of Equity Incentive Schemes of Listed Companies” issued by the China Securities Regulatory Commission (CSRC) became effective (Huang et al., 2013)[14]. Equitybased compensation is far from the most popular incentive methods in China when compared with cash compensation. Though there are limited studies on the relationship between managerial cash compensation and firm risk-taking. Cohen et al. (2000) mention in their research that the traditional compensations (including salary, bonus and stock) will have incentive to keep low volatility of the firm [11]. However, no empirical evidence supports this conclusion.

Moreover, all the above mentioned literatures are based on the experience of developed countries (Ghosh et al., 2011) [15]. China has had rapid and dramatic growth and has become world's largest developing economy. But there has been only limited focus on Chinese listed firms. Diffuse ownership is the basic background of most researches in the developed countries; however, dominant shareholder and government control are still major characteristics of most of Chinese listed companies. Therefore, further investigations of China's empirical evidence are necessary.

Managerial compensation and firm leverage. One way to increase firm risk is to increase leverage (Coles et al., 2006) [5]. Capital structure is value-critical since debt is alternative "governance structures" rather than just "financial instruments" (Williamson, 2010) [16]. Debt financing enhances firm's value, since it reduces total agency costs (Jensen and Meckling, 1976) [1]. In addition, empirical work confirms that an increase in leverage is associated with higher stock prices and a decrease in leverage with lower stock prices (Masulis, 1988) [17]. However, higher debt also creates higher possibility of bankruptcy, which is costly to managers. Thus, management will be risk averse and choose leverage ratio that is lower than optimal although a higher leverage will maximize firm value.

Mehran (1992) mentioned that many capital structure models are based on the critical assumption that managers always act in the shareholders' best interests (e.g., Modigliani and Miller, the static trade-off theory, and the pecking order theory) [2]. Management incentives have long been neglected when considering the determinant of firm leverage.

Can management incentives act as solution to shareholder-manager conflict? Several studies attempt to link management incentive to firm leverage. The direction of the relationship between managerial compensation and firm leverage is unclear. On one hand, some researchers find managerial incentive can motivate managers to adopt a higher leverage ratio. For example, Mehran (1992) takes a sample of US manufacturing firms and found a positive relationship between executive compensation and firm's leverage ratio, since compensation contracts can be designed to relate managers' compensation to their performance [2]. Coles et al. (2006) empirically investigated a sample of Standard \& Poor's database for the period 1992-2002 [5]. They find higher sensitivity of CEO wealth to stock volatility will implement higher book leverage. On the other hand, several studies hold the opposite opinion. Friend and Lang (1998) provide empirical evidence that debt ratio is negatively related to management's shareholding, reflecting the non-diversifiable risk of debt to management [18]. Douglas (2006) predicts a negative relationship between leverage and pay-for-performance through theoretical deduction [19]. Besides, Smith and Watts (1982) suggest that corporate investment policy, financial policy, dividend 
policy, and compensation policy are interrelated [20]. There may exist endogeneity problem caused by joint determination between management incentive and firm leverage ratio.

In summary, this paper develops two competitive hypotheses regarding the relationship between managerial cash compensation and firm leverage choice. One is risk-taking hypothesis, and the other is risk-averse hypothesis.

Risk-taking hypothesis. As the managerial compensation in the form of cash (including salary and bonus) increases, the interest of management and stockholders converge. Consequently, as cash compensation increases, managements' wealth grows, and managements will pursue leverage decisions that have higher risk-taking level. Thus, we derive the risk-taking hypothesis as follows:

Hypothesis 1a: Management cash compensation is positively associated with firm leverage ratio.

Risk-averse hypothesis. In contrast to the risk-taking hypothesis, it is possible that managerial cash compensation may be negatively related to firm leverage ratio. When cash compensation increases, the management's personal portfolio becomes less diversified and thus management becomes more risk averse and more likely to pursue low leverage level to mitigate the overall risk of the firm in order to avoid potential impairment to their career (Smith and Stulz, 1985; John et al., 2008) [21,22]. Based on this counter argument, we formulate the risk-averse hypothesis as follows:

Hypothesis 1b: Management cash compensation is negatively associated with firm leverage ratio. Managerial compensation and leverage in government controlled firms. Considering the contextualization of market reforms in China, will the relationship between managerial compensation and firm leverage choice be affected by different types of controlling ownership in Chinese listed firms? Will management be more risk taking or risk averse when cash compensation increases in government controlled firms? This part is designed to compare the cash compensation-leverage ratio sensitivities in firms with different controlling ownership type.

Prior to the Chinese enterprise reform in 1978, almost all firms in China are controlled by government (Firth et al., 2006) [8]. The activities of the firms were controlled by a planned economic system. The privatization took place in 1978, aiming to give more autonomy and incentive to managers. However, many of the SOEs were partially privatized and the State still retains sufficient shares to maintain voting control (Firth et al., 2006) [8].

Compared with managements of private firms, managements of government controlled firms are less likely to be motivated by cash compensation and thus will be more risk averse when making firm leverage decisions. First, due to the insider control problem caused by owners' absence, managements in government controlled firms are more likely to be risk averse in making leverage decisions. The more important the private benefits are, the more conservative the insiders are likely to be in directing corporate decisions (John et al., 2008)[22]. Second, the compensation level of managements in government controlled firms is under severe regulation. Managerial compensation level in government controlled firms is usually associated with employee compensation, thus is relatively low when compared with managerial compensation level of private firms and is lack of incentive to the executive team (Chen et al., 2005)[23]. Third, the appointment of managements is typically controlled by the government in government controlled firms. Therefore political interferences are inevitable in running of business. Political goals (such as providing employment opportunities) are pursued by government controlled firms besides economic goals, which will hinder potential incentive effect of cash compensation to managements of government controlled firms (Bai and $\mathrm{Xu}, 2005$ )[24]. Hence, we posit the following hypothesis:

Hypothesis 2: In government controlled firms, cash compensation will have less incentive effect for managements to increase firm leverage ratio than in private firms. 


\section{Method}

Measure model. To test the relation between cash compensation and firm leverage choice, this paper relates the level of management payment to firm book leverage after controlling for firm size, industry, sales amount and other firm characteristics. Some empirical studies suggest that firm leverage ratio also has an impact on managerial incentive compensation (John and John, 1993)[25]. Thus managerial compensation and firm leverage ratio may be jointly determined. To avoid possible endogeneity problem, this study employs simultaneous equations model to achieve unbiased parameter estimates. The econometric model has two equations. The first has book leverage as dependent variable and the second has management cash compensation as dependent variable. In order to see if government control has an impact on the relationship between managerial compensation and firm leverage choice, we include main and interactive effects of the type of control. This research also controls other firm characteristics in both equations. To conform to the underlying reasoning for simultaneous equations, this paper uses contemporaneous rather than lag values of variables.

LEV is the book leverage of the firm. PAY is the log of aggregate top three highest cash compensation of the management team. STATE is a dummy variable coded one (1) if the ultimate controller of the firm is a State bureaucratic agency. STATE is interacted with PAY. ROA is the return on assets of the firm. RET is the stock returns for the year considering dividend re-investment. SIZE is the log of the total assets. FIXASSET is net fix asset scaled by total asset. GROW is year-on-year percentage change of the sales. SALE is the sales amount scaled by total asset. INDUSTRY and YEAR dummy variables are included to control for the impact of industry and year.

Sample selection. This study uses the company annual reports as source of information for managerial compensation, leverage ratio, and other firm characteristic variables. The initial sample includes all available listed firms of Shanghai Stock Exchange and Shenzhen Stock Exchange for the period of 2003-2015 provided by Chinese Stock Market Accounting Research (CSMAR) database. Financial companies are excluded from the study due to a lack of critical data (A. Low, 2009)[7]. We also exclude special treatment (ST) and *ST companies because of their unique financial characteristics, and firms with incomplete financial information. In the end, the sample consists of an unbalanced panel of 1671 firms, with a total of 13720 firm-year observations.

\section{Empirical Results}

Summary statistics. Table 1 presents summary statistics on cash compensation and leverage ratio and other control variables. Mean (median) leverage ratio is 0.47 (0.48). Mean (median) PAY is 13.84 (13.87), that means the mean (median) cash compensation of the aggregate top three highest management is RMB1,432,712 (RMB 1,059,600).

Table 1. Summary Statistics

\begin{tabular}{lccccc}
\hline Variable & Mean & Median & Standard Deviation & Min & Max \\
\hline LEV & 0.47 & 0.48 & 0.29 & 0.01 & 23.80 \\
PAY & 13.84 & 13.87 & 0.83 & 9.21 & 17.24 \\
STATE & 0.50 & 0.00 & 0.50 & 0.00 & 1.00 \\
ROA & 0.05 & 0.04 & 0.07 & -2.06 & 0.48 \\
RET & 0.32 & 0.08 & 0.86 & -0.87 & 9.12 \\
SIZE & 21.93 & 21.75 & 1.23 & 16.88 & 28.51 \\
FIXASSET & 0.27 & 0.24 & 0.18 & 0.00 & 0.97 \\
GROW & 0.26 & 0.14 & 3.76 & -1.00 & 400.68 \\
SALE & 21.37 & 21.23 & 1.42 & 11.12 & 28.69
\end{tabular}


Managerial cash compensation and risk-taking in leverage choice. In this section we examine whether cash compensation will induce managements to implement risky leverage choices, and also the impact of ultimate controller type. As stated earlier, cash compensation can either boost or hinder managements to make risky leverage choices. Table 2 reports estimates from simultaneous.

While we focus on the relationship between management cash compensation and firm leverage ratio, our specifications include management payment, leverage and control variables to represent forces that drive cash compensation together with firm leverage ratio choice. To address the possibility that there are other omitted variables, all specifications throughout include industry and year fixed effects. Since management cash compensation and firm leverage choice are endogenously determined in the system, 3SLS is used to estimate the system (as shown in Column 1 in Table 2) and 2SLS is used as robustness test (as shown in Column 2 in Table 2).

Table 2. Simultaneous Equations of Management Cash Compensation and Firm Leverage Choice

\begin{tabular}{|c|c|c|c|c|}
\hline & \multicolumn{2}{|c|}{ Column 1: 3SLS } & \multicolumn{2}{|c|}{ Column 2: 2SLS } \\
\hline & Eq.1: LEV & Eq.2: PAY & Eq.1: LEV & Eq.2: PAY \\
\hline PAY & $\begin{array}{c}0.5055^{* * *} \\
(12.65)\end{array}$ & & $\begin{array}{c}0.4624^{* * *} \\
(10.3)\end{array}$ & \\
\hline LEV & & $\begin{array}{c}11.1502^{* * *} \\
\quad(5.73)\end{array}$ & & $\begin{array}{c}11.1502^{* * *} \\
\quad(5.72)\end{array}$ \\
\hline STATE & $\begin{array}{c}0.0360^{* * *} \\
(5.04)\end{array}$ & $\begin{array}{c}-0.1208^{* *} \\
(-2.3)\end{array}$ & $\begin{array}{c}0.0323^{* * *} \\
(4.37)\end{array}$ & $\begin{array}{c}-0.1208^{* *} \\
(-2.29)\end{array}$ \\
\hline STATE* PAY & $\begin{array}{c}-0.1635^{* * *} \\
(-8.17)\end{array}$ & & $\begin{array}{c}-0.1674^{* * *} \\
(-7.66)\end{array}$ & \\
\hline GROW & $\begin{array}{c}0.0031^{* * *} \\
(3.62)^{* * *}\end{array}$ & $\begin{array}{c}-0.0173^{* * *} \\
(-2.58)\end{array}$ & $\begin{array}{c}0.0030^{* * *} \\
(3.42)^{* * *}\end{array}$ & $\begin{array}{c}-0.0173^{* * *} \\
(-2.57)\end{array}$ \\
\hline ROA & $\begin{array}{c}-3.2494^{* * *} \\
(-30.61)\end{array}$ & $\begin{array}{l}26.1899^{* * *} \\
\quad(6.25)\end{array}$ & $\begin{array}{l}-3.1435^{* * *} \\
(-26.71)\end{array}$ & $\begin{array}{l}26.1899^{* * *} \\
(6.23)\end{array}$ \\
\hline RET & $\begin{array}{c}0.0449^{* * *} \\
(7.49)\end{array}$ & $\begin{array}{c}-0.3957^{* * *} \\
(-4.94)\end{array}$ & $\begin{array}{c}0.0445^{* * *} \\
(7.4)\end{array}$ & $\begin{array}{c}-0.3956^{* * *} \\
(-4.93)\end{array}$ \\
\hline FIXASSET & $\begin{array}{l}0.2033^{* * *} \\
(7.31)\end{array}$ & & $\begin{array}{c}0.1894^{* * *} \\
(6.39)\end{array}$ & \\
\hline SIZE & $\begin{array}{c}-0.0576^{* * *} \\
(-5.77)\end{array}$ & & $\begin{array}{c}-0.0454^{* * *} \\
(-3.95)\end{array}$ & \\
\hline SALE & & $\begin{array}{c}-0.4991^{* * *} \\
(-4.03)\end{array}$ & & $\begin{array}{c}-0.4991^{* * *} \\
(-4.02)\end{array}$ \\
\hline $\begin{array}{l}\text { Industry fixed } \\
\text { effects }\end{array}$ & YES & YES & YES & YES \\
\hline Year fixed effects & YES & YES & YES & YES \\
\hline $\mathrm{R} 2$ & 0.0823 & 0.0988 & 0.0639 & 0.0988 \\
\hline $\begin{array}{ll}\text { No. } & \text { of } \\
\text { observations }\end{array}$ & 13720 & 13720 & 13720 & 13720 \\
\hline
\end{tabular}

Note. z-statistics are within parentheses. ${ }^{* * *}, * *$, and * indicate statistical significance at $1 \%, 5 \%$, and $10 \%$ levels, respectively. Intercepts are not reported.

According to the results from simultaneous estimation presented in Column 1 of Table 2, the coefficient on PAY in Eq. 1 is positive $(\alpha=0.5055)$ and significant at $1 \%$ level. The estimated coefficient on LEV in Eq.2 is also positive $(\beta=11.1502)$ and significant at $1 \%$ level. These results 
provide strong evidence of a joint determination between management cash compensation and firm leverage ratio. Management cash compensation and firm leverage choice seem to move together and have positive effect on each other. Therefore Hypothesis $1 a$ is supported and Hypothesis $1 b$ is rejected.

STATE has a significant and positive effect on firm book leverage $(\alpha=0.0360, \mathrm{P}<1 \%)$ and has a significantly negative effect on management cash payment $(\beta=-0.1208, \mathrm{P}<5 \%)$. These results are consistent with the literature and the analysis above. Firms controlled by State bureaucratic agencies usually have higher leverage ratio and pay less to their top management team. The coefficient on interactive effect of controller type and cash compensation (STATE* PAY) in Eq.1 is negative $(\alpha=-$ 0.1635 ) and significant at $1 \%$ level. In other words, for firms controlled by State bureaucratic agencies, cash compensation will have less incentive effect for management to implement risky leverage choices when compared with private firms. Therefore Hypothesis 2 is supported.

GROW, ROA and RET affect both firm leverage ratio and management cash compensation. GROW and RET a positive effect on firm leverage ratio and a negative effect on management cash payment. ROA has a negative effect on firm leverage ratio and a positive effect on management cash payment. These contradicted effects manifest that tradeoff should be made to achieve joint optimization between increasing firm leverage ratio and keeping top management motivated by cash compensation. Besides, FIXASSET and SIZE have positive and negative effect on firm leverage choice, respectively. SALE is negatively associated with cash compensation.

Robustness checks. Column 2 of Table 2 reports the results of robustness test using 2SLS for the simultaneous equation system. As shown, all the results are consistent with using 3SLS. The coefficient on PAY in Eq. 1 is positive $(\alpha=0.4624)$ and significant at $1 \%$ level. The estimated coefficient on LEV in Eq. 2 is also positive $(\beta=11.1502)$ and significant at $1 \%$ level. STATE has a significant and positive effect on firm book leverage $(\alpha=0.0323, \mathrm{P}<1 \%)$ and has a significant and negative effect on management cash payment $(\beta=-0.1208, \mathrm{P}<5 \%)$. The coefficient on interactive effect of controller type and cash compensation (STATE* PAY) in Eq. 1 is negative $(\alpha=-0.1674)$ and significant at $1 \%$ level.

\section{Summary}

Manager-stockholder conflict may induce top management team to be risk averse and refuse to increase firm leverage ratio in order to avoid potential impairment to their career. The role of managerial compensation has long been neglected to solve the conflict. We extend this literature by investigating the joint determined relationship between managerial compensation and firm leverage decision to see whether management cash compensation can motivate management to be risk-taking in making firm leverage decisions. Our pooled sample contains 13720 firm-year observations over the time period from 2003 to 2015. Furthermore, we take China's contextualization into consideration and investigate the role of government control in moderating the relationship between managerial compensation and firm leverage choice.

Several important conclusions emerge from our analysis. First, the empirical evidence in this paper support the joint determined relationship between management cash compensation and firm leverage choice, they have positive effect on each other. This reconciles previous inconsistent empirical researches and fills the gap for not considering managerial compensation in firm leverage decisions. Second, this paper chooses Chinese listed firms as sample to investigate the potential impact of transition economy. The empirical results show that cash compensation will have less incentive effect for management in firms controlled by State bureaucratic agencies to increase leverage ratio. This suggests that further ownership reform is needed in transition economies like China. Also, other 
methods of management incentives such as equity based compensation should be encouraged to be introduced to Chinese listed firms to offer better motivation to top managements.

\section{References}

[1] M. C. Jensen, W. H. Meckling, Theory of the firm: Managerial behavior, agency costs and ownership structure, Journal of Financial and Economics. 3(1976) 305-360.

[2] H.Mehran,. Executive Incentive Plans, Corporate Control, and Capital Structure. Journal of Financial \& Quantitative Analysis. 27 (1992), 539-560.

[3] M.Carlson, A.Lazrak,. Leverage Choice and Credit Spreads when Managers Risk Shift. Journal of Finance. 65(2010), 2323-2362.

[4] W. R. Guay,. The sensitivity of CEO wealth to equity risk: an analysis of the magnitude and determinants. Journal of Financial Economics. 53 (1999), 43-71.

[5] J. L. Coles, N. D. Daniel, L. Naveen, Managerial incentives and risk-taking. Journal of Financial Economics. 79(2006), 431-468.

[6] S. Rajgopal, T. Shevlin, Empirical evidence on the relation between stock option compensation and risk taking. Journal of Accounting and Economics. 33(2002), 145-171.

[7] A.Low, Managerial risk-taking behavior and equity-based compensation. Journal of Financial Economics. 92 (2009), 470-490.

[8] M. Firth, P. M. Y. Fung, O. M. Rui, Corporate performance and CEO compensation in China. Journal of Corporate Finance. 12 (2006), 693-714.

[9] M. Faccio, M. T. Marchica, R. Mura, Large shareholder diversification and corporate risk- taking. Review of Financial Studies. 24(2011) 3601-3641.

[10] M. C. Jensen,. Agency Cost Of Free Cash Flow, Corporate Finance, and Takeovers. American Economic Review. 76(1986), 323-329.

[11] R. B. Cohen, B. J. Hall, L. M. Viceira, Do executive stock options encourage risk-taking. Unpublished Manuscript. (2000).

[12] S. A. Ross, Compensation, Incentives, and the Duality of Risk Aversion and Riskiness. Journal of Finance. 59(2004) 207-225.

[13] J. Grant, G. Markarian, A. Parbpnetti, CEO Risk-Related Incentives and Income Smoothing. Contemporary Accounting Research. 26(2009), 1029-1065.

[14] Y. T. Huang, M. C. Wu, S. L. Liao,. The relationship between equity-based compensation and managerial risk taking: evidence from China. Emerging Markets Finance \& Trade. 49(2013) 107-125.

[15] C. Ghosh, E. Giambona, J. P. Harding, C. F. Sirmans, How Entrenchment, Incentives and Governance Influence REIT Capital Structure. Journal of Real Estate Finance \& Economics. 43 (2011) 39-72.

[16] O. E. Williamson, Transaction Cost Economics: The Natural Progression. American Economic Review. 100(2010) 673-690.

[17] R. W. Masulis,.The Debt/Equity Choice, Cambridge, Ballinger, 1988. 
[18] I. Friend, H. P. L. Lang, An Empirical Test of the Impact of Managerial Self-interest on Corporate Capital Structure. Journal of Finance. 43 (1988) 271-281.

[19] A. V. S. Douglas, Capital Structure, Compensation and Incentives. Review of Financial Studies. 19(2006) 605-632.

[20] C. W. Smith, R. L. Watts, Incentive and Tax Effects of Executive Compensation Plans. Australian Journal of Management. 7(1982) 139-157.

[21] C. W. Smith, R. M. Stulz, The Determinants of Firms' Hedging Policies. Journal of Financial \& Quantitative Analysis. 20(1985) 391-405.

[22] K. John, L. Litov, B. Yeung, Corporate Governance and Risk Taking. Journal of Finance. 63(2008) 1679-1728.

[23] D. H. Chen, X. Y. Chen, H. L. Wan, Regulation and Non-pecuniary Compensation in Chinese SOEs [In Chinese]. Economic Research Journal. 2(2005) 92-101.

[24] C. E. Bai, L. C. Xu, Incentives for CEOs with multitasks: evidence from Chinese state-owned enterprises. Journal of Comparative Economics. 33(2005) 517-539.

[25] T. A. John, K. John, Top-management compensation and capital structure. Journal of Finance. 48(1993) 949-974. 